S.I. Avina, O.Y. Loboyko, N.B. Markova, O.L. Sincheskul, I.V. Bahrova

\title{
RESEARCH INTO PLATINUM-BASED TAILINGS DERIVED FROM A RECOVERY BOILER OF THE PRODUCTION OF NITRIC ACID AND ITS PREPARATION FOR THE EXTRACTION OF PLATINUM GROUP METALS
}

\begin{abstract}
National Technical University «Kharkiv Polytechnic Institute», Kharkiv, Ukraine
The paper deals with the characterization of platinum-based tailings derived from a recovery boiler of the production of nitric acid. The composition of the tailings was determined and the calcination process was investigated in order to improve the extraction of platinum group metals (PGM) into concentrate. According to the results of the research, the size of the majority $(81.6 \%)$ of particles of the tailings is less than $0.1 \mathrm{~mm}$. The results of X-ray diffraction and laser mass-spectral analyses indicate that the tailings contain $7.82 \mathrm{wt} . \%$ of platinum, $1.56 \mathrm{wt} . \%$ of palladium and $0.09 \mathrm{wt} . \%$ of rhodium. It also contains carbon and ferromagnetic iron. It is shown that magnetic separation used as a preparatory stage allows extracting about $20 \mathrm{wt} . \%$ of ferromagnetic iron from platinum-based tailings of nitric acid production. The influence of various technological parameters on calcination of PGM tailings from recovery boiler was investigated in the temperature range of 1023 to $1173 \mathrm{~K}$. The largest mass loss of the tailings is up to $9 \mathrm{wt} . \%$ at $1123 \mathrm{~K}$ during $60 \mathrm{~min}$ of calcination. X-ray structural analysis of calcinated samples of PMG tailings from recovery boiler of nitric acid production revealed that palladium oxide decomposes and carbon is burned out in the course of calcination. The mass loss of carbon is $1.34 \mathrm{wt} \%$ during $60 \mathrm{~min}$ of the heat treatment. It was found out that calcination leads to cracking of PGM which improves extracting process of platinum-based tailings of nitric acid production.
\end{abstract}

Keywords: platinum group metals, catalyst, nitric acid, ammonia, oxidation, slurry, technology.

DOI: $10.32434 / 0321-4095-2018-121-6-107-112$

\section{Introduction}

Nowadays the global usage of platinum group metals (PGM) is getting higher from year to year unlike their average production rate that stays the same. Chemical industry is one of the main consumers of platinum. Platinum is used as catalyst in various technological processes including the production of nitric acid at the stage of ammonia oxidation [1-4]. There are losses of platinum group metals from the surface of catalyst nets in this process as the result of their oxidation, destruction and followed carryover. Small parts of PGM deposit on the surfaces of the equipment. Lifetime of PGM catalyst is $2800-3400$ hours. After this term, catalyst loss comes up to $30-50 \%$ of the total catalyst weight.

According to the studies [5-8], the main reasons of PGM loss are the oxidation of platinum with the formation of volatile platinum oxides and catalytic erosion of the wire surface of nets during the catalytic process at high temperature. Due to these factors, the surface of the platinum wire becomes friable. It allows the flowing gas to capture small parts of metallic Pt and remove them from the reaction zone. In order to solve this problem, special absorption masses and mechanical filters made of quartz wool, asbestos, fiberglass, etc. were developed. The absorption masses are based on the mixture of $\mathrm{CaO}$ and $\mathrm{Al}_{2} \mathrm{O}_{3}[9,10]$. The capture rate of $\mathrm{Pt}$ in both methods is $40-50 \%$. Nowadays, chemical industry uses catching mixtures based on alloys $\mathrm{Pd} / \mathrm{W}-5$ or $\mathrm{Pd} / \mathrm{Ni}-5$ (95\% of palladium and $5 \%$ of tungsten or $5 \%$ nickel) $[11,12]$. During the operation of these packages, smooth surface of the initial catching wire transforms into conglomerate of large Pt grains with the size of up to $0.1 \mathrm{~mm}$. However, tungsten or nickel completely burn out and the capture rate comes up to $85-94 \%$.

There is an extra source of PGM $(0.1-60 \mathrm{wt} . \%)$

(C) S.I. Avina, O.Y. Loboyko, N.B. Markova, O.L. Sincheskul, I.V. Bahrova, 2018

Research into platinum-based tailings derived from a recovery boiler of the production of nitric acid and its preparation for the extraction of platinum group metals 


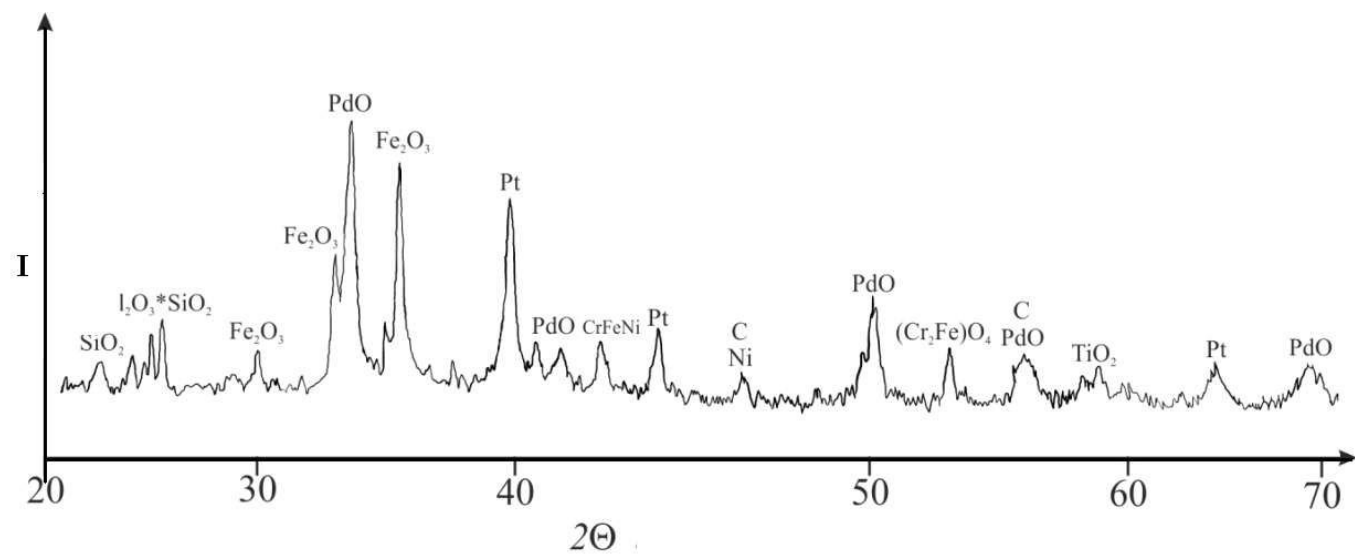

Fig. 1. X-ray pattern of the tailings derived from a recovery boiler

in this case. It is the slurries obtained by cleaning surfaces of equipment located after the ammonia oxidation reactor. Despite this fact, there is a big problem in PGM recycling connected with the presence of poorly soluble oxides and base metals in the slurries.

The purpose of the research was to substantiate and develop an efficient way to utilize the slurries from the equipment of nitric acid production.

\section{Experimental design}

As a research object, we used a sample of the tailings from a recovery boiler. The lifetime of platinum nets in the contact oxidation reactor was 3100 hours. Their fractional composition was determined by the method of manual dry sieve analysis with a set of sieves No. 004, 01, 025, 05, 08; the results are presented in Table 1 . The tailings were dried beforehand at $105-110^{\circ} \mathrm{C}$ to achieve a constant weight with the accuracy of $0.1 \%$.

Fractional composition of the tailings

Table 1

\begin{tabular}{c|c}
\hline Fractional composition & Content, wt.\% \\
\hline$>0.5 \mathrm{~mm}$ & 3.66 \\
\hline $0.5-0.25 \mathrm{~mm}$ & 3.62 \\
\hline $0.25-0.1 \mathrm{~mm}$, & 11.50 \\
\hline $0.1-0.04 \mathrm{~mm}$ & 31.79 \\
\hline$<0.04 \mathrm{~mm}$ & 49.81 \\
\hline
\end{tabular}

According to the obtained results, the size of the majority of particles $(81.6 \%)$ of the tailings is less than $0.1 \mathrm{~mm}$.

X-ray structural analysis revealed that the tailings contain $\mathrm{Pt}$ in metal state and $\mathrm{Pd}$ in oxidized state. There were also other compounds: $\mathrm{Al}_{2} \mathrm{O}_{3}, \mathrm{SiO}_{2}$, $\mathrm{Fe}_{2} \mathrm{O}_{3}, \mathrm{SiO}_{2}, \mathrm{TiO}_{2}, \mathrm{C}, \mathrm{Ni}$ and others (Fig. 1). The definition accuracy of a particular phase is from 2 to $5 \%$.
The obtained data on the state of PGM are confirmed by findings of various authors. Chemical erosion results from platinum evaporation from the catalyst surface. It is considered [5] that ammonia oxidation process proceeds only on platinum oxides but not on metal platinum. The evaporation of the oxides leads to irreversible losses of Pt. In addition, mechanical erosion of the catalyst nets occurs as a result of dust bombarding (ammonia-air mixture always contain some small amount of dust).

The quantitative composition of PGM in tailings collected from the recovery boiler was determined by the methods of atomic absorption spectrometry and laser mass spectrometry. The results exhibited showed that tailings contains (wt.\%): $7.82 \mathrm{Pt}$; $1.34 \mathrm{Pd}, 0.12 \mathrm{Rh}[13,14]$. They also contain elements that present in the ammonia-air mixture.

Derivatographic analysis of nitrate acid tailings showed the occurrence of four processes in the temperature range of $283 \mathrm{~K}$ to $1273 \mathrm{~K}$ (Fig. 2).

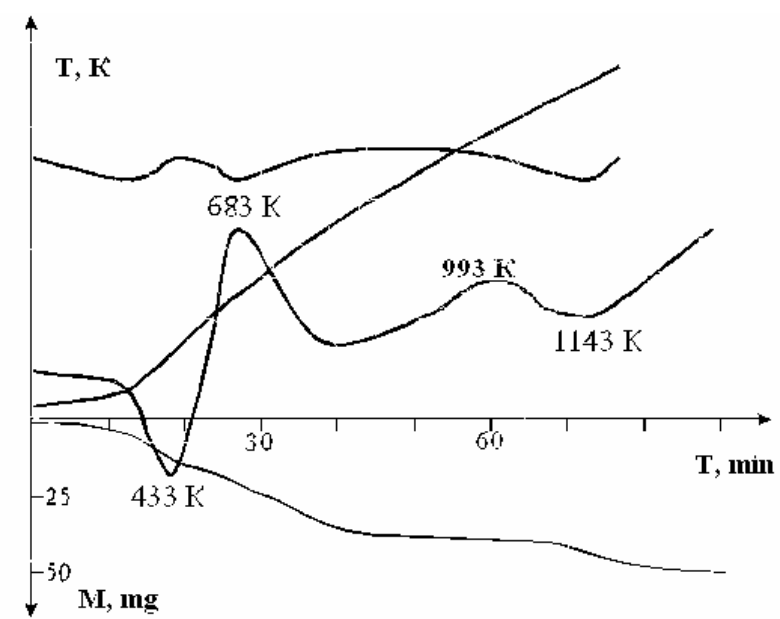

Fig. 2. Derivatograms of tailings derived from a recovery boiler 
The first process is endothermic, it is associated with the removal of physically bound water from platinum sludge from nitrate production. This process starts at $373 \mathrm{~K}$ and ends at $443 \mathrm{~K}$. The weight loss is about $3 \%$.

The second process is exothermic. It begins at $613 \mathrm{~K}$ and practically ends at $693 \mathrm{~K}$. In this case, the allotropic transition of $\alpha-\mathrm{Fe}_{2} \mathrm{O}_{3}$ to $\gamma-\mathrm{Fe}_{2} \mathrm{O}_{3}$ and their decomposition occur. This is also confirmed by the results of X-ray analysis. The weight loss of the tailings sample is about $1 \%$.

The third process is exothermic, it is associated with the burnout of carbon which begins at $873 \mathrm{~K}$ and practically ends at $993 \mathrm{~K}$. The weight loss of the sludge sample is about $5 \%$.

The fourth process is endothermic and connected with the decomposition of $\mathrm{PdO}$ with the formation of metallic palladium. This process takes place within the temperature range of 1093-1183 K and leads to the weight loss of about $4 \%$.

\section{Results and discussion}

Nowadays the main utilization method of slurries is a selective leaching of PGM with subsequent extraction into a concentrate. The research of slurries from recovery boiler of nitric acid production showed that it also contains carbon which promotes foam formation at the stage of extraction and reduces its efficiency.

In order to solve this problem, we proposed to calcine tailings which leads to the carbon removal and, at the same time, provides the transformation of hard-soluble compounds of PGM to acid-soluble ones. Derivatographic analysis of tailings revealed that this effect can be achieved due to the decomposition of PGM oxides and complex salts. The temperature range of this process is from 1093 to $1183 \mathrm{~K}$. The mass loss is about $4 \mathrm{wt} . \%$.

In addition, significant amount of ferromagnetic iron in platinum-based tailings interferes with the PGM extraction. That's why its removal is a priority task. Magnetic separation was proposed to be used before calcination of PGM tailings obtained from a recovery boiler of nitric acid production.

The results of the analysis of elemental composition of PGM tailings derived from the recovery boiler after magnetic separation are given in Table 2.

The analysis of the data summarized in Table 2 allows concluding that up to 20 wt.\% of ferromagnetic iron can be removed by magnetic separation from PGM tailings.

The influence of various technological parameters on the calcination of PGM tailings from recovery boiler at temperature range of 1023 to $1173 \mathrm{~K}$
Table 2

Elemental composition of the tailings

\begin{tabular}{c|c|c}
\hline \multirow{2}{*}{$\begin{array}{c}\text { Main } \\
\text { components }\end{array}$} & \multicolumn{2}{|c}{ Content, wt.\% } \\
\cline { 2 - 3 } & Initial tailings & After magnetic separation \\
\hline $\mathrm{Pt}$ & 7.82 & 10.46 \\
\hline $\mathrm{Pd}$ & 1.56 & 2.08 \\
\hline $\mathrm{Rh}$ & 0.09 & 0.12 \\
\hline $\mathrm{C}$ & 4.02 & 5.36 \\
\hline $\mathrm{Na}$ & 1.33 & 1.78 \\
\hline $\mathrm{Mg}$ & 0.29 & 0.39 \\
\hline $\mathrm{Al}$ & 8.57 & 11.43 \\
\hline $\mathrm{Si}$ & 13.24 & 17.65 \\
\hline $\mathrm{K}$ & 0.66 & 0.88 \\
\hline $\mathrm{Ca}$ & 0.40 & 0.53 \\
\hline $\mathrm{Ti}$ & 2.21 & 2.95 \\
\hline $\mathrm{Cr}$ & 8.51 & 11.35 \\
\hline $\mathrm{Mn}$ & 0.60 & 0.80 \\
\hline $\mathrm{Fe}$ & 42.79 & 23.32 \\
\hline $\mathrm{Ni}$ & 3.35 & 4.47 \\
\hline & &
\end{tabular}

Influence of technological parameters on the tailings calcination

\begin{tabular}{c|c|c|c|c}
\hline \multirow{2}{*}{$\begin{array}{c}\text { Time, } \\
\text { min }\end{array}$} & \multicolumn{4}{|c}{ Loss of the tailings, wt.\% } \\
\cline { 2 - 5 } & $1023 \mathrm{~K}$ & $1073 \mathrm{~K}$ & $1123 \mathrm{~K}$ & $1173 \mathrm{~K}$ \\
\hline 15 & 6.340 & 7.05 & 7.140 & 7.190 \\
\hline 30 & 7.010 & 7.68 & 7.960 & 8.040 \\
\hline 60 & 7.864 & 7.89 & 9.020 & 9.020 \\
\hline 90 & 7.867 & 7.892 & 9.024 & 9.022 \\
\hline 120 & 7.871 & 7.896 & 9.026 & 9.026 \\
\hline 150 & 7.872 & 7.897 & 9.026 & 9.026 \\
\hline
\end{tabular}

is shown in Table 3 .

The obtained data on weight loss indicates that the rate of the calcination is enough at temperature of $1123 \mathrm{~K}$. The rate increases with increasing the temperature and the process ends at $1273 \mathrm{~K}$. It is shown in Table 3 that the largest weight loss of the

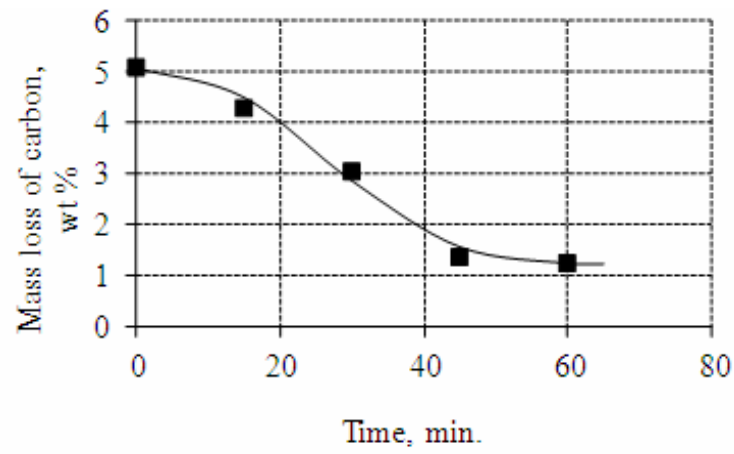

Fig. 3. Intluence of calcination duration on carbon weight loss at $1123 \mathrm{~K}$ 


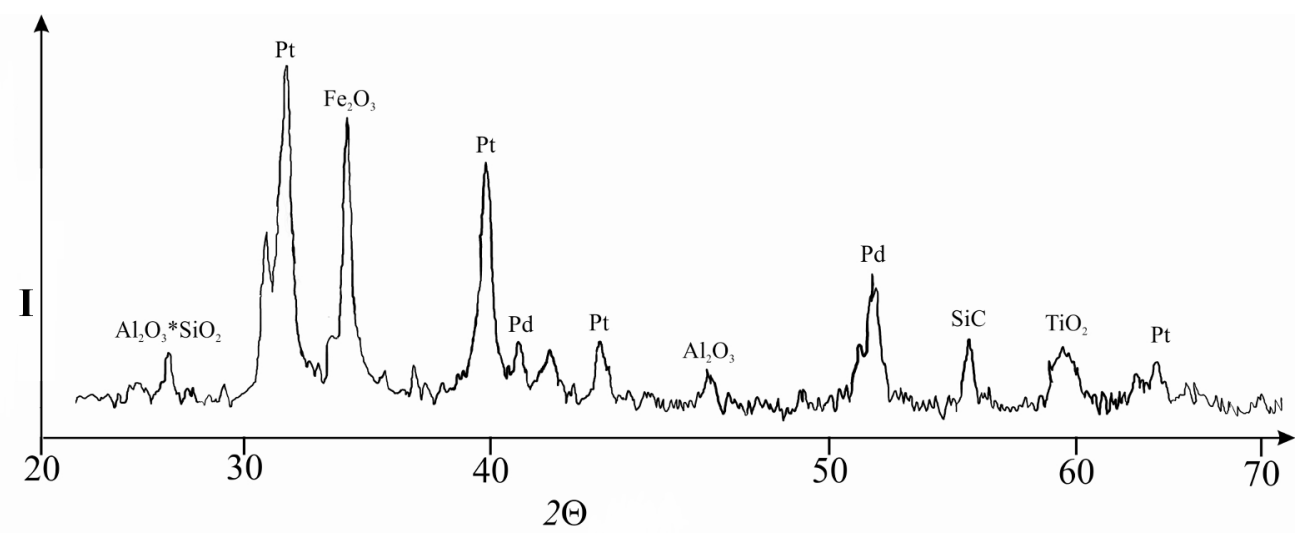

Fig. 4. X-ray pattern of calcinated tailings derived from a recovery boiler

tailings is up to $9 \mathrm{wt} \%$ at $1123 \mathrm{~K}$ during $60 \mathrm{~min}$. It has been found out that an increase of calcination duration leads to an increase of carbon weight loss. After $60 \mathrm{~min}$. of the treatment, it significantly reduces up to 1.34 wt.\% (Fig. 3).

The results of the investigation of the phase composition of calcinated samples of PMG tailings showed that they contain the following compounds: $\mathrm{Al}_{2} \mathrm{O}_{3}, \mathrm{SiO}_{2}, \mathrm{Fe}_{2} \mathrm{O}_{3}, \mathrm{Al}_{2} \mathrm{O}_{3}, \mathrm{TiO}_{2}, \mathrm{Pt}, \mathrm{Pd}$ and others (Fig. 4). X-ray structural analysis of calcinated samples of PMG tailings from recovery boiler of nitric acid production exhibited that palladium oxide decompose and carbon burns out during the calcination.

It was also found that the calcination promotes cracking of PMG and extracting them from tailings. The composition of PMG in tailings was determined by atomic absorption spectrometry as follows (wt.\%): 13.48 Pt, 3.56 Pd and 0.28 Rh.

Thus, the rational conditions of calcination process of PMG tailings have been determined. The temperature range of $1073-1173 \mathrm{~K}$ was chosen because platinum group metals are converted into acid-soluble form at these temperatures. The optimal duration of the calcination is $60 \mathrm{~min}$. Its increase does not lead to essential growth of carbon mass loss.

\section{Conclusions}

Tailings obtained by cleaning surfaces of equipment located after the ammonia oxidation reactor contains 7.82 wt.\% of Pt, 1.34 wt.\% of $\mathrm{Pd}$ and 0.12 wt. $\%$ of Rh. The qualitative and quantitative composition of platinum-based tailings may vary depending on the composition of the platinum nets and on their lifetime. Additional stages of platinumbased tailings processing have been proposed. They are magnetic separation and carbon calcination. They allow achieving a high degree of platinum group metals extraction from these slurries. The main features and quantitative dependencies of this process were determined. These findings allow improving the process of PMG extracting from the slurries of the production of nitric acid.

\section{REFERENCES}

1. Tovazhnyans 'kyy L.L. Tekhnologiya zv'yazanogo azotu. - NTU «KhPI», Kharkiv, 2007. - 536 p.

2. Karavaev M.M., Zasorin A.P., Kleshchev N.F. Katalytycheskoe okislenie ammiaka. - Moscow: Khimiya, 1983. $-232 \mathrm{p}$.

3. Il'in A.P., Kunin A.V. Proizvodstvo azotnoi kisloty. St. Petersburg: Lan', 2013. - 247 p.

4. Rdzawski Z.M., Stobrawa J.P., Szynowski J. Microstructure stability of the PtRh alloys used for catalytic ammonia oxidation // Journal of Achievements in Materials and Manufacturing Engineering. - 2007. - Vol.24. - No. 1. - P.106114.

5. Catalytic ammonia oxidation on platinum: mechanism and catalyst restructuring at high and low pressure / R. Imbihl, A. Scheibe, Y.F. Zeng, S. Gunther, R. Kraehnert, V.A. Kondratenko, M. Baerns, W.K. Offermans, A.P.J. Jansen, R.A. van Santen // Physical Chemistry Chemical Physics. - 2007. - Vol.9. - P.3522-3540.

6. Loboyko A.Y. Kataliticheskie i massoobmennye protsessy pod davleniem $\mathrm{v}$ tekhnologii neorganicheskikh veshchestv. Moscow: Osnova, 1993. - 216 p.

7. Avina S.I., Savenkov A.S. Reaktsiya okysnennya amiaku. Vtrata platynoyidnogo katalizatora // Khimichna Promyslovist' Ukrayiny. - 2010. - Vol.5. - P.7-10.

8. Analiz poter' platiny v proizvodstve azotnoi kisloty na agregatakh UKL-7 / Avina S.I., Markova N.B., Bagrova I.V., Mikisha G.V., Shlein Y.V. // Bulletin of KrNU. - 2015. - Vol.4. - P.142-147.

9. Platynoyidnyi katalizator okysnennya amiaku. Mekhanizm utvorennya ta ulovlennya vtrat / Loboyko O.Y., Hryn’ G.I., Tovazhnyans'kyy L.L., Markova N.B., Avina S.I. // 
Khimichna Promyslovist' Ukrayiny. - 2016. - Vol.1. - P.3-6.

10. Loboyko A.Y., Lavrenko A.A. Issledovaniye fizikokhimicheskikh svoistv sorbenta platinovogo katalizatora // Bulletin of NTU «KhPI». - 1988. - Vol.12. - P.44-48.

11. Savenkov A.S., Avina S.I., Loboyko V.A. Kinetika poter' platinoidov v reaktsii kataliticheskogo okisleniya ammiaka // Zhurnal Prikladnoy Khimii. - 2012. - Vol.85. - P.1587-1594.

12. Brushtejn E.A., Vanchurin V.I., Yashchenko A.V. Promyshlennyi monitoring poter' platinoidov pri okislenii ammiaka v agregatah UKL-7 // Catalysis in Industry. - 2014. Vol.3. - P.59-65.

13. Avina S.I., Loboyko O.Y., Honcharov I.I. Utylizatsiya shlamu, shcho mistyt' metaly platynovoyi grupy // Bulletin of Dniprovsk State Technical University. - 2008. - P.51-52.

14. Avina S.I., Loboyko O.Y. Vplyv tekhnolohichnykh parametriv na vidnovlennya metaliv platynovoyi grupy // Bulletin of Odessa Polytechnic University. - 2013. - Vol.3. - P.249-252.

Received 30.05.2018

\section{ДОСЛІДЖЕННЯ ПЛАТИНОВМІСНОГО ШЛАМУ 3 КОТЛА-УТИЛІЗАТОРА ВИРОБНИЦТВА НІТРАТНОЇ КИСЛОТИ ТА ЙОГО ПІДГОТОВКА ДО ВИЛУЧЕННЯ МЕТАЛІВ ПЛАТИНОВОЇ ГРУПИ}

\section{С.І. Авіна, О.Я. Лобойко, Н.Б. Маркова, О.Л. Сінческул, І.В. Багрова}

В даній роботі досліджено вміст платиновмісного шламу, який зібраний з котла-утилізатора виробництва нітратної кислоти та процес його випалу з метою удосконалення технології вилучення металів платинової групи у концентрат. За результатами фракційного аналізу показано, що 81,6\% платиновмісного шламу має розмір фракцій <0,1 мм. Результати досліджень рентгеноструктурного та лазерного мас-спектрального аналізу свідчать про те, що в платиновмісному шламі міститься (мас.\%): 7,82 платини; 1,56 паладію; 0,09 родію, а також такі речовини як вуглець та феромагнітне залізо. Показано, що магнітна сепарація як підготовча стадія дозволяе вилучити приблизно 20 мас.\% феромагнітного заліза із платиновмісного шламу виробництва нітратної кислоти. Досліджено вплив різноманітних технологічних параметрів на процес випалу шламу нітратного виробництва в температурному інтервалі від 1023 до 1173 К. Встановлено, що найбільша втрата ваги шламу при температурі $1123 \mathrm{~K}$ та часу випалу 60 хв становить близько 9 мас.\% Рентгенофазовий аналіз випаленого зразка платиновмісного шламу виробництва нітратної кислоти підтвердив, що при випалюванні розкладається оксид паладію і випалюється вуглець. Втрата маси вуглецю при термічному обробленні протягом 60 хвилин складає 1,34 мас.\%. В результаті досліджень виявлено, що в процесі випалу відбувається «розкриття» платиноїдів, що поліпшує процес вилучення металів платинової групи із платиновмісного шламу виробництва нітратної кислоти.

Ключові слова: метали платинової групи, каталізатор, нітратна кислота, аміак, окиснення, шлам, технологія.

\section{RESEARCH INTO PLATINUM-BASED TAILINGS DERIVED FROM A RECOVERY BOILER OF THE PRODUCTION OF NITRIC ACID AND ITS PREPARATION FOR THE EXTRACTION OF PLATINUM GROUP METALS}

S.I. Avina, O.Y. Loboyko, N.B. Markova, O.L. Sincheskul, I.V. Bahrova

National Technical University «Kharkiv Polytechnic Institute», Kharkiv, Ukraine

The paper deals with the characterization of platinum-based tailings derived from a recovery boiler of the production of nitric acid. The composition of the tailings was determined and the calcination process was investigated in order to improve the extraction of platinum group metals (PGM) into concentrate. According to the results of the research, the size of the majority (81.6\%) of particles of the tailings is less than $0.1 \mathrm{~mm}$. The results of $X$-ray diffraction and laser mass-spectral analyses indicate that the tailings contain $7.82 \mathrm{wt} . \%$ of platinum, $1.56 \mathrm{wt} . \%$ of palladium and $0.09 \mathrm{wt} . \%$ of rhodium. It also contains carbon and ferromagnetic iron. It is shown that magnetic separation used as a preparatory stage allows extracting about 20 wt. \% offerromagnetic iron from platinum-based tailings of nitric acid production. The influence of various technological parameters on calcination of PGM tailings from recovery boiler was investigated in the temperature range of 1023 to $1173 \mathrm{~K}$. The largest mass loss of the tailings is up to 9 wt.\% at $1123 \mathrm{~K}$ during $60 \mathrm{~min}$ of calcination. X-ray structural analysis of calcinated samples of PMG tailings from recovery boiler of nitric acid production revealed that palladium oxide decomposes and carbon is burned out in the course of calcination. The mass loss of carbon is $1.34 \mathrm{wt} . \%$ during $60 \mathrm{~min}$ of the heat treatment. It was found out that calcination leads to cracking of PGM which improves extracting process of platinumbased tailings of nitric acid production.

Keywords: platinum group metals; catalyst; nitric acid; ammonia; oxidation; slurry; technology.

\section{REFERENCES}

1. Tovazhnyans'kyy L.L., Tekhnologiya zv'yazanogo azotu [Technology of fixed nitrogen]. NTU «KhPI» Publishers, Kharkiv, 2007. 536 p. (in Ukrainian).

2. Karavaev M.M., Zasorin A.P., Kleshchev N.F., Kataliticheskoe okislenie ammiaka [Catalytic oxidation of ammonia]. Khimiya, Moscow, 1983. 232 p. (in Russian).

3. Il'in A.P., Kunin A.V., Proizvodstvo azotnoi kisloty [Production of nitric acid]. Lan' Publishers, St. Petersburg, 2013. 247 p. (in Russian).

4. Rdzawski Z.M., Stobrawa J.P., Szynowski J. Microstructure stability of the PtRh alloys used for catalytic ammonia oxidation. Journal of Achievements in Materials and Manufacturing Engineering, 2007, vol. 24, no. 1, pp. 106-114.

5. Imbihl R., Scheibe A., Zeng Y.F., Gunther S., Kraehnert R., Kondratenko V.A., Baerns M., Offermans W.K., Jansen A.P.J., van Sante R.A. Catalytic ammonia oxidation on platinum: mechanism and catalyst restructuring at high and low pressure. Physical Chemistry Chemical Physics, 2007, vol. 9, pp. 3522-3540.

6. Loboyko A.Y., Kataliticheskie i massoobmennye protsessy pod davleniem $v$ tekhnologii neorganicheskikh veshchestv [Catalytic and mass exchanged processes in technology of inorganic substances]. Osnova Publishers, Moscow, 1993. 216 p. (in Russian).

Research into platinum-based tailings derived from a recovery boiler of the production of nitric acid and its preparation for the extraction of platinum group metals 
7. Avina S.I., Savenkov A.S. Reaktsiya okysnennya amiaku. Vtrata platynoyidnogo katalizatora [Ammonia oxidation reaction. Platinoid catalyst loss]. Khimichna Promyslovist' Ukrayiny, 2010, vol. 5, pp. 7-10. (in Ukrainian).

8. Avina S.I., Markova N.B., Bagrova I.V., Mikisha G.V., Shlein Y.V. Analiz poter' platiny v proizvodstve azotnoi kisloty na agregatakh UKL-7 [Analysis of platinum loss in a unit of nitric acid production UCL-7]. Bulletin of KrNU, 2015, vol. 4, pp. 142-147. (in Russian).

9. Loboyko O.Y., Hryn' G.I., Tovazhnyans'kyy L.L., Markova N.B., Avina S.I. Platynoyidnyy katalizator okysnennya amiaku. Mekhanizm utvorennya ta ulovlennya vtrat [Platinoid catalyst of ammonia oxidation]. Khimichna Promyslovist' Ukrayiny, 2016, vol. 1, pp. 3-6. (in Ukrainian).

10. Loboyko A.Y., Lavrenko A.A. Issledovaniye fizikokhimicheskikh svoistv sorbenta platinovogo katalizatora [The research of physicochemical characteristics of the sorbent of platinum catalyst]. Bulletin of NTU «KhPI», 1988, vol. 12, pp. 44-48. (in Russian).

11. Savenkov A.S., Avina S.I., Loboyko V.A. Kinetics of loss of platinum group metals in catalytic oxidation of ammonia. Russian Journal of Applied Chemistry, 2012, vol. 85, pp. 15241530.

12. Brushtein E.A., Vanchurin V.I., Yashchenko A.V. Promyshlennyi monitoring poter' platinoidov pri okislenii ammiaka $v$ agregatah UKL-7 [Industrial platinoid loss monitoring in ammonia oxidation process in a UCL-7 unit]. Catalysis in Industry, 2014, vol. 3, pp. 59-65. (in Russian).

13. Avina S.I., Loboyko O.Y., Honcharov I.I. Utylizatsiya shlamu, shcho mistyt' metaly platynovoyi grupy [Recycling of the slurry that contains metals of platinum group]. Bulletin of Dnipro State Technical University, 2008, pp. 51-52. (in Ukrainian).

14. Avina S.I., Loboyko O.Y., Vplyv tekhnologichnykh parametriv na vidnovlennya metaliv platynovoyi grupy [An influence of process-dependent parameters on reduction of platinum group metals]. Bulletin of Odessa Polytechnic University, 2013, vol. 3, pp. 249-252. (in Ukrainian). 